\title{
A PILOT STUDY OF AEROSOLIZED AMILORIDE FOR THE TREATMENT OF LUNG DISEASE IN CYSTIC FIBROSIS
}

\author{
Michael R. Knowles, M.D., Nina L. Ghurch, M.S., William E. Waltner, M.D., \\ James R. Yankaskas, M.D., Peter Gilligan, Ph.D., Malcolm King, Ph.D., Lloyd J. Edwards, M.S., \\ Ronald W. Helms, Ph.D., and Righard C. Bougher, M.D.
}

\begin{abstract}
Excessive active absorption of sodium is a unique abnormality of the airway epithelium in patients with cystic fibrosis. This defect is associated with thickened mucus and poor clearance of airway secretions and may contribute to the pulmonary disease in these patients. To study whether the inhibition of excessive absorption of sodium might affect the course of lung disease in cystic fibrosis, we performed a double-blind, crossover trial comparing aerosolized amiloride ( $5 \mathrm{mmol}$ per liter; $3.5 \mathrm{ml}$ four times daily), a sodium-channel blocker, with vehicle alone.

Fourteen of the 18 adult patients initially enrolled in the study completed the one-year trial (25 weeks for each treatment). The mean ( \pm SEM) loss of forced vital capacity (FVC) was reduced from $3.39 \pm 1.13 \mathrm{ml}$ per day during treatment with vehicle alone to $1.44 \pm 0.67 \mathrm{ml}$ per day dur-
\end{abstract}

$\mathrm{I}^{\mathrm{N}}$ $\mathrm{N}$ the airway epithelium of patients with cystic fibrosis, the combination of excessive absorption of sodium $^{1,2}$ and defective regulation of the secretory chloride channel of the apical membrane $e^{3-6}$ probably leads to the dehydration of airway secretions, as reported in clinical studies. ${ }^{7}$ These ion-transport defects probably contribute to the abnormal rheologic features and poor clearance of airway secretions, ${ }^{8}$ obstruction of airflow, and chronic bacterial infection of the airways. ${ }^{9}$ The sodium-channel blocker amiloride inhibits the excessive absorption of sodium (and liquid) in vitro ${ }^{1,10}$ and in vivo ${ }^{11}$ when applied to the luminal surface of the airway epithelium of patients with cystic fibrosis. These findings suggested that the long-term inhalation of amiloride might improve the viscosity, elasticity, and clearance of secretions, protect the airways from intraluminal obstruction, and improve airflow..$^{11,12}$

The present study was designed as a preliminary investigation of the safety and efficacy of long-term treatment with aerosolized amiloride for airway disease in cystic fibrosis. A double-blind, crossover design was employed, and each treatment period (25 weeks) was preceded by a course of parenteral antibiotics to standardize the recent use of antibiotics

From the University of North Carolina, Chapel Hill (M.R.K., N.L.C. W.E.W., J.R.Y., P.G., L.J.E., R.W.H., R.C.B.), and the University of Alberta, Edmonton (M.K.). Address reprint requests to Dr. Knowles at the Division of Pulmonary Diseases, 724 Burnett-Womack Bldg., CB\# 7020, University of North Carolina, Chapel Hill, NC 27599-7020.

Supported by grants from the Cystic Fibrosis Foundation (RRDP, RO15, and A014), the National Institutes of Health (HL34322 and MO1 RR00046), the Canadian Cystic Fibrosis Foundation, and the Mr. and Mrs. James Snyder Fund.

In accordance with the Journal's policy, the authors have stated that Drs. Knowles and Boucher have an interest in the patent for the use of aerosolized amiloride in the treatment of lung disease in cystic fibrosis.

*See NAPS document no. 04768 for 16 pages of supplementary material Order from NAPS c/o Microfiche Publications, P.O. Box 3513, Grand Central Station, New York, NY 10163-3513. Remit in advance (in U.S. funds only) $\$ 7.75$ for photocopies or $\$ 4$ for microfiche. Outside the U.S. and Canada add postage of $\$ 4.50$ ( $\$ 1.50$ for microfiche postage) ing treatment with amiloride $(P<0.04)$. A measured index of sputum viscosity and elasticity was abnormal during treatment with vehicle alone and improved during treatment with amiloride. Calculated indexes of mucociliary and cough clearance also improved during amiloride treatment. No systemic, respiratory, or subjective toxic effects of amiloride were noted.

We conclude from this preliminary study that aerosolized amiloride can be safely administered to adults with cystic fibrosis. The slowing of the loss of FVC and the improvement in sputum viscosity and elasticity suggest a beneficial clinical effect. Aerosolized amiloride deserves further evaluation in the treatment of lung disease in patients with cystic fibrosis. (N Engl J Med 1990; 322: 1189-94.)

among the patients and enhance the delivery of the aerosol.

\section{Methods}

\section{Study Subjects}

Eighteen patients were recruited into the study. Guidelines for selection included the diagnosis of cystic fibrosis on the basis of clinical criteria and the results of sweat tests for chloride, partial pressure of arterial oxygen greater than 55 torr without chronic retention of carbon dioxide, normal renal function, and no longterm use of systemic steroids. Informed consent was obtained under the auspices of the Human Rights Committee of the University of North Carolina.

\section{Study Design}

A randomized, double-blind, crossover study was designed.* The nominal length of each treatment period was 25 weeks. Each period was preceded by 10 to 14 days of parenteral treatment with tobramycin and ceftazidime. Treatment with all respiratory medicines (oral and aerosolized antibiotics and bronchodilators) was withdrawn, and was witheld during the study period unless guidelines for reinstitution were met.

Two base-line measurements of pulmonary function were obtained on separate days after the completion of parenteral antibiotic treatment. Each patient also had a physical examination, bloodchemistry tests, chest radiography, quantitative microbiologic testing of sputum, complete blood count, urinalysis, and 24-hour measurement of urinary aldosterone excretion at the same time. Aerosol treatment was initiated after base-line measurements were obtained, and physical examinations, spirometry, quantitative microbiologic testing, measurements of serum electrolytes, and renalfunction testing were also performed at three-to-six-week intervals from week 3 to week 25. At the end of each period (at about week 25), duplicate or single measurements were obtained as at base line, and aerosol treatment was then discontinued. Sputum was obtained from six patients for biorheologic studies of viscosity and elasticity at the end of each period. ${ }^{13} \mathrm{~A}$ two-to-four-week washout period and treatment with parenteral antibiotics preceded the second period of aerosol therapy.

According to specific criteria, unscheduled visits and interventions with oral antibiotics (except quinolones) and bronchodilators were allowed for the treatment of mild exacerbations of disease. The therapy was discontinued after two to four weeks, but patients could receive a second (or third) course of therapy. 
Criteria were also established for episodes of illness (usually major hemoptysis) that required "extraordinary intervention" with parenteral antibiotics. Safety was monitored by a blinded, nonparticipating observer who periodically reviewed coded clinical and laboratory data.

\section{Aerosol Solution and Delivery of the Drug}

Amiloride hydrochloride was dissolved in 0.3 percent saline ( 5 mmol per liter; pH 7.0). A nebulizer (DeVilbiss 646) and compressed-air generator (Pulmoaide, DeVilbiss) were used to nebulize and deliver $3.5 \mathrm{ml}$ of drug or vehicle ( 0.3 percent saline) four times daily. With proper inhalational technique, this approach deposits an effective dose of amiloride (about $0.1 \mathrm{mmol}$ per liter) on airway surfaces. ${ }^{14,15}$

\section{Tests}

Pulmonary-function tests (spirometric measurements before and after use of a bronchodilator and measurement of single-breath diffusing capacity [Gould 2400], measurement of arterial blood gases [Radiometer ABL 30], and plethysmographic measurement of lung volumes [Jaeger]) were performed according to American Thoracic Society standards ${ }^{16}$ at least three hours after the patient had arisen and three hours after the administration of the aerosol. Quantitative bacterial cultures of sputum were performed with a technique equivalent to quantitation using mucolytic agents. ${ }^{17,18}$ Sputum for biorheologic testing was obtained three hours after the administration of aerosol at the end of each study period in a manner designed to minimize salivary contamination. ${ }^{13}$ Rheologic studies used the technique of the magnetic oscillating sphere, ${ }^{19}$ and the percentage of solids was measured after microwave drying. Chest radiographs were graded according to a published scoring system. ${ }^{20}$ The urinary aldosterone level was measured by radioimmunoassay (SmithKline BioScience). Twelve pulmonary and systemic symptoms or measures (chest tightness; shortness of breath; wheezing; cough during the first two hours of the day, during the rest of the day, or during sleep; hemoptysis; color, consistency, and volume of sputum; appetite; and general well-being) were graded weekly by the patients, using an ordinal scale and a diary designed for the study.*

\section{Statistical Analysis}

In both treatment periods 3 of the 14 patients who completed the study had episodes of acute illness that qualified for extraordinary parenteral antibiotic therapy. After the intervention, the patients resumed aerosol therapy and completed the treatment period so that toxicity could be evaluated. In these three patients, only data collected before the extraordinary intervention were used in our analyses of efficacy.

The use of complete, balanced analysis-of-variance or multipleanalyses-of-variance methods was precluded because of the irregular timing of visits. Analyses were performed by two statistical methods selected before the study. In method 1, the mean change from base line (i.e., the difference between the mean base-line value and the mean of the values during treatment) with vehicle and amiloride was computed for each subject. In method 2, the slopes from unweighted simple linear regression (including base-line data) for each subject for each period and for each variable (forced vital capacity [FVC] and forced expiratory volume in one second $\left[\mathrm{FEV}_{1}\right]$, for example) were analyzed. The difference between the slopes during treatment with vehicle and treatment with amiloride was computed for each subject. Comparisons of treatments as assessed by methods 1 and 2 were based on these differences in unweighted, two-tailed, paired t-tests and signed-rank tests, which yielded similar outcomes except as indicated. A separate analysis was performed for each response variable. To test for differences in

*See NAPS document no. 04768 for 16 pages of supplementary material. Order from NAPS c/o Microfiche Publications, P.O. Box 3513, Grand Central Station, New York, NY 10163-3513. Remit in advance (in U.S. funds only) $\$ 7.75$ for photocopies or $\$ 4$ for microfiche. Outside the U.S. and Canada add postage of $\$ 4.50$ ( $\$ 1.50$ for microfiche postage). rheologic features and bacterial counts in the sputum obtained near the end of each study period, paired t-tests were employed with logtransformed data. All hypotheses regarding efficacy and safety were specified before the analysis began. A Type I error rate of 0.05 was used to judge statistical significance. All but one investigator remained blinded to the assigned treatments during the analyses. Results are reported as means \pm SEM unless otherwise indicated.

\section{Results}

Of the 18 patients who were recruited, 3 withdrew from the study (after 3,10 , and 18 weeks) because they were unable to follow the protocol. One other patient withdrew (after 13 weeks) after hemolytic anemia associated with Epstein-Barr-virus seroconversion developed; a subsequent trial of aerosolized amiloride in the patient produced no adverse effect. Table 1 outlines the clinical features of the 14 patients who completed the study.

Seven of the 14 patients were randomly assigned to vehicle and 7 to amiloride for the first period. The mean duration of treatment with vehicle and amiloride was well matched ( 24.7 weeks in each period), and there was no seasonal bias in either treatment period. There was an equal degree of compliance during treatment with vehicle $(79.0 \pm 6.0$ percent of scheduled doses) and amiloride (80.3 \pm 4.7 percent).

\section{Efficacy}

Before treatment with vehicle and treatment with amiloride, the base-line FVC (3.66 \pm 0.28 and $3.60 \pm$ 0.29 liters, respectively) and $\mathrm{FEV}_{1}(2.25 \pm 0.24$ and $2.22 \pm 0.25$ liters, respectively) were nearly identical. The mean decrease in FVC from base line (analyzed according to method l) during treatment with vehicle $(296 \pm 79 \mathrm{ml})$ was approximately twice as large as that during treatment with amiloride $(160 \pm 53 \mathrm{ml}$; $P<0.04)$. The data on FVC are shown in Table 2. The mean decrease in $\mathrm{FEV}_{1}$ during treatment with vehicle $(291 \pm 95 \mathrm{ml})$ was not significantly different from that during treatment with aerosolized amiloride

Table 1. Clinical Characteristics of the 14 Patients Who Completed the Study.*

\begin{tabular}{|c|c|}
\hline Characteristic & Value \\
\hline Male sex (no.) & 8 \\
\hline Age $(y r)$ - range $($ median $)$ & $18-37(25)$ \\
\hline Hospitalizations (no.) $\dagger$ & $0.9 \pm 0.3$ \\
\hline FVC ( $\%$ of predicted $) \ddagger$ & $81.2 \pm 5.6$ \\
\hline $\mathrm{FEV}_{1}$ (\% of predicted $) \ddagger$ & $60.1 \pm 5.9$ \\
\hline $\begin{array}{l}\text { Microbiologic findings (no. of patients) } \S \\
\text { Pseudomonas aeruginosa } \\
\text { Staphylococcus aureus } \\
\text { Aspergillus fumigatus } \mathbb{1} \\
\text { Mycobacterium avium-intracellulare }\end{array}$ & $\begin{array}{r}14 \\
8 \\
4 \\
2\end{array}$ \\
\hline $\begin{array}{l}\text { Medications (no. of patients) } \\
\text { Oral contraceptives } \\
\text { Insulin }\end{array}$ & $\begin{array}{l}5 \\
1\end{array}$ \\
\hline 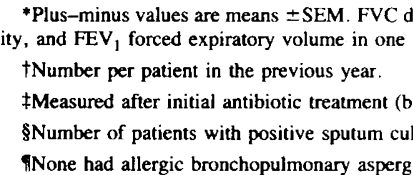 & $\begin{array}{l}\text { ed vital capac- } \\
\text { eriod 1). } \\
\text { evious year. }\end{array}$ \\
\hline
\end{tabular}


Table 2. Changes in Mean Forced Vital Capacity (FVC) during the Study Periods.

\begin{tabular}{|c|c|c|c|c|c|c|c|}
\hline \multirow[t]{3}{*}{ Patient No. } & \multicolumn{3}{|c|}{ VeHICLE } & \multicolumn{3}{|c|}{ AMILORIDE } & \multirow[t]{3}{*}{ DIFFERENCE* } \\
\hline & $\begin{array}{l}\text { AVERAGE } \\
\text { BASE-LINE } \\
\text { FVC }\end{array}$ & $\begin{array}{l}\text { AVERAGE FVC } \\
\text { DURING } \\
\text { TREATMENT }\end{array}$ & CHANGE & $\begin{array}{l}\text { AVERAGE } \\
\text { BASE-LINE } \\
\text { FVC }\end{array}$ & $\begin{array}{l}\text { AVERAGE FVC } \\
\text { DURING } \\
\text { TREATMENT }\end{array}$ & CHANGE & \\
\hline & & & & $m l$ & & & \\
\hline 1 & 3450 & 2925 & 525 & 2825 & 2760 & 65 & 460 \\
\hline 2 & 4445 & 4190 & 255 & 4500 & 4490 & 10 & 245 \\
\hline 3 & 6090 & 5067 & 1023 & 5960 & 5617 & 343 & 680 \\
\hline 4 & 2565 & 2588 & -23 & 2365 & 2543 & -178 & 155 \\
\hline 5 & 4475 & 3934 & 541 & 4250 & 3810 & 440 & 101 \\
\hline 6 & 4245 & 3952 & 293 & 4430 & 3985 & 445 & -152 \\
\hline 7 & 3055 & 2547 & 508 & 2715 & 2392 & 323 & 185 \\
\hline 8 & 4070 & 4108 & -38 & 4020 & 3880 & 140 & -178 \\
\hline 9 & 2870 & 2646 & 224 & 2945 & 2732 & 213 & 11 \\
\hline 10 & 3720 & 3635 & 85 & 3730 & 3758 & -28 & 113 \\
\hline 11 & 2970 & 2890 & 80 & 3055 & 2960 & 95 & -15 \\
\hline 12 & 3200 & 3125 & 75 & 3420 & 3387 & 33 & 42 \\
\hline 13 & 4330 & 3805 & 525 & 4415 & 4048 & 367 & 158 \\
\hline 14 & 1815 & 1741 & 74 & 1755 & 1787 & -32 & 106 \\
\hline Mean & 3664 & 3361 & 296 & 3599 & 3439 & 160 & 137 \\
\hline Median & 3585 & 3380 & 240 & 3575 & 3572 & 118 & 109 \\
\hline Standard error & 282 & 234 & 79 & 291 & 265 & 53 & 60 \\
\hline$P$ value by t-test & & & 0.003 & & & 0.010 & 0.039 \\
\hline $\begin{array}{l}\text { P value by signed- } \\
\text { rank test }\end{array}$ & & & 0.002 & & & 0.014 & 0.038 \\
\hline
\end{tabular}

${ }^{*}$ Change during treatment with vehicle minus change during treatment with amiloride.

$(202 \pm 51 \mathrm{ml} ; \mathrm{P} \approx 0.20)$. After treatment with an inhaled bronchodilator, a similar pattern was ob-

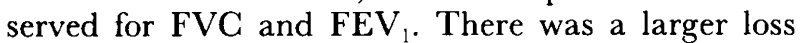
of FVC during treatment with vehicle $(222 \pm 50 \mathrm{ml})$ than during treatment with amiloride $(117 \pm 57 \mathrm{ml}$; $\mathrm{P}=0.03$ by signed-rank test and 0.11 by t-test), but the decrease in $\mathrm{FEV}_{1}$ during treatment with vehicle $(225 \pm 50 \mathrm{ml})$ was not significantly different from the decrease during treatment with amiloride $(170 \pm 54 \mathrm{ml} ; \mathrm{P}=0.32$ by signed-rank test and 0.23 by t-test). No carry-over effects between the two periods were detected. The mean duration of expiration for FVC was the same during the two periods (10.0 \pm 0.7 seconds).

The analysis of slopes (method 2) is illustrated in Figure 1. The mean rate of decrease in FVC during treatment with vehicle $(3.39 \pm 1.13 \mathrm{ml}$ per day) was reduced by more than half during treatment with amiloride $(1.44 \pm 0.67 \mathrm{ml}$ per day; $\mathrm{P}<0.04)$. The difference in the rate of decrease in $\mathrm{FEV}_{1}$ between the two periods was not statistically significant (vehicle, $3.21 \pm 1.11 \mathrm{ml}$ per day; amiloride, $2.09 \pm 0.86 \mathrm{ml}$ per day; $P \approx 0.09$ ).

Matched pairs of sputum samples obtained from six patients who completed both periods without a need for parenteral antibiotics were analyzed for biorheologic features ${ }^{21}$ and the results compared with normal values (Table 3). $\log G^{*} 1$ and $\log G^{*} 100$, indexes of the mechanical impedance of mucus, were different for amiloride and vehicle. The loss tangents $(\tan \delta 1$ and $\tan \delta 100$ ), indexes of the ratio of viscous to elastic strain, were not different. Calculated indexes of muco- ciliary clearance $e^{21}$ and cough clearance ${ }^{22}$ differed significantly between vehicle and amiloride (Table 3 ). The rheologic values of sputum obtained during long-term treatment with aerosolized amiloride approximated normal values. The solid content of the sputum obtained during treatment with vehicle $(7.5 \pm 3.2$ percent $)$ did not differ from that of the sputum obtained during treatment with amiloride (8.3 \pm 4.1 percent) .

Several monitored indexes were not altered by amiloride treatment. Measures of nonspirometric lung function at the beginning and end of each treatment period were available only for the patients who completed both periods without parenteral antibiotics $(\mathrm{n}=11)$. There was no difference between the vehicle and amiloride periods with respect to changes in arterial blood gases (alveolar-arterial gradient, $0.3 \pm 1.7$ and $1.1 \pm 1.9$ torr, respectively) or diffusing capacity $(-0.9 \pm 0.5$ and $+0.3 \pm 0.8 \mathrm{ml}$ per $\mathrm{mm} \mathrm{Hg}$ per minute). Bacterial densities - the number of organisms $\left(\log _{10}\right)$ per milliliter of sputum were similar in the sputum from patients without antibiotic intervention and in the sputum from all patients. Total bacterial densities were $8.16 \pm 0.18$ and $8.13 \pm 0.20$, and densities of Pseudomonas aeruginosa were $7.96 \pm 0.21$ and $7.79 \pm 0.35$ during 12 to 25 weeks of treatment with vehicle and amiloride, respectively. No differences were noted in bacterial densities or the incidence of positive cultures for Staphylococcus aureus between the vehicle and amiloride periods.

\section{Interventions}

The therapeutic interventions are summarized in Table 4. The use of oral antibiotics, bronchodilators, and prednisone did not differ between the vehicle and amiloride periods when it was analyzed on the basis of individual or grouped data.

\section{Safety}

No evidence of pulmonary or systemic toxicity emerged from analyses of pulmonary function, symptoms, physical examinations, or laboratory tests (Table 5). No difference in the incidence of aspergillus or candida species in sputum cultures was observed during treatment with amiloride, nor was any new microbial or multidrug-resistant organism identified.

\section{Discussion}

Several features appeared to be critical in the design of this study of long-term inhalation of amiloride in the treatment of lung disease in patients with cystic 
fibrosis. First, effective delivery of the drug to the airway surfaces was required. The concentration of amiloride in airway-surface liquid needed to produce effective blockade (more than 90 percent inhibition) of the absorption of sodium in patients with cystic fibrosis is about $0.01 \mathrm{mmol}$ per liter (the median effective dose is $0.001 \mathrm{mmol}$ per liter). ${ }^{1,10,11}$ Because amiloride is rapidly cleared from human airways (half time, about 40 minutes), ${ }^{14,15}$ a peak concentration of about $0.5 \mathrm{mmol}$ per liter on airway surfaces four times daily is required to maintain an effective concentration. Optimizing the system of nebulizing the liquid, we achieved a peak concentration of about $0.08 \mathrm{mmol}$ per liter of amiloride in the bronchi of patients with cystic fibrosis. ${ }^{15}$ We accepted this dose because respir-
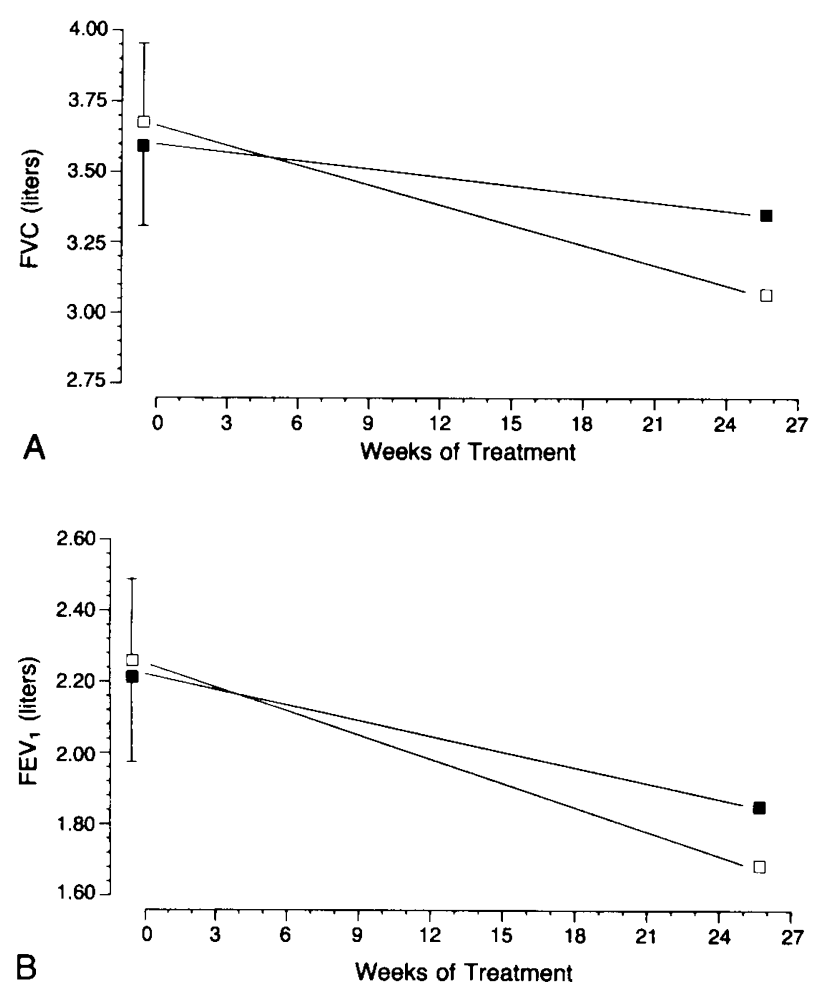

Figure 1. Changes in Mean Forced Vital Capacity (FVC) and Forced Expiratory Volume $\left(\mathrm{FEV}_{1}\right)$ during the Study Periods.

Panel $A$ shows the mean ( \pm SEM) base-line FVC and the mean slope of FVC as a function of time during treatment with vehicle $(\square)$ and amiloride $(\square)$. The slopes reflect 7.3 and 7.1 measurements per patient ( $n=14$ ), including base-line values, for vehicle and amiloride, respectively ( $P<0.04$ for the differences in slopes). FVC decreased by $3.39 \pm 1.13 \mathrm{ml}$ per day during treatment with vehicle, and by $1.44 \pm 0.67 \mathrm{ml}$ per day during treatment with amiloride.

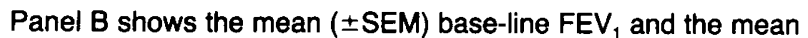
slope of FEV as a function of time during treatment with vehicle $(\square)$ and amiloride $(\square)$. The slopes reflect 7.3 and 7.1 measurements per patient $(n=14)$, including base-line values, for vehicle and amiloride, respectively $(P=0.09$ for the differences in slopes). $F E V_{1}$ decreased by $3.21 \pm 1.11 \mathrm{ml}$ per day during treatment with vehicle, and by $2.09 \pm 0.86 \mathrm{ml}$ per day during treatment with amiloride.
Table 3. Biorheologic Features of Airway Secretions after LongTerm Treatment with Vehicle and Amiloride.*

\begin{tabular}{lccc}
\hline \hline MEASUREMENT $\dagger$ & $\begin{array}{c}\text { VeHICLE } \\
(\mathrm{N}=6)\end{array}$ & $\begin{array}{c}\text { AMILORIDE } \\
(\mathrm{N}=6)\end{array}$ & $\begin{array}{c}\text { Normal } \\
\text { VALUES }^{21}\end{array}$ \\
Log G*1 $(1 \mathrm{rad} / \mathrm{sec})$ & $2.92 \pm 0.10$ & $2.41 \pm 0.14 \ddagger$ & $2.17 \pm 0.08$ \\
Log G*100 $(100 \mathrm{rad} / \mathrm{sec})$ & $3.32 \pm 0.09$ & $2.67 \pm 0.13 \ddagger$ & $2.56 \pm 0.08$ \\
Tan $\delta 1(1 \mathrm{rad} / \mathrm{sec})$ & $0.41 \pm 0.02$ & $0.32 \pm 0.04$ & $0.29 \pm 0.16$ \\
Tan $\delta 100(100 \mathrm{rad} / \mathrm{sec})$ & $0.95 \pm 0.06$ & $1.04 \pm 0.06$ & $0.93 \pm 0.06$ \\
Mucociliary-clearance index & $0.66 \pm 0.03$ & $0.84 \pm 0.06 \ddagger$ & $0.91 \pm 0.02$ \\
Cough-clearance index & $0.73 \pm 0.09$ & $1.51 \pm 0.18 \ddagger$ & $1.52 \pm 0.03$ \\
\hline
\end{tabular}

*Plus-minus values are means \pm SEM

$\left\lceil\log G^{*} 1\right.$ and $\log G^{*} 100$ are indexes of the mechanical impedance of mucus. The loss $\operatorname{tangents}(\tan \delta 1$ and $\tan \delta 100)$ are indexes of the ratio of viscous to elastic strain.

$\ddagger \mathrm{P}<0.05$ for the comparison with values after treatment with vehicle.

able amiloride was available only in this formulation and we expected compliance to be poor if dosage frequency exceeded four times daily. Second, because no information is available regarding outcome variables pertinent to aerosolized diuretic agents, we selected measures of outcome on the basis of the hypothesis that amiloride would inhibit the excessive absorption of sodium and would hydrate secretions and improve their biorheologic properties and clearance from the airways. The results of a spirometric test were selected as the chief criteria of efficacy because the test measures both the retention of airway secretions ${ }^{23}$ and the functional benefit to the patient. ${ }^{9}$ Measurements that assess the rheologic features of sputum more directly were undertaken to explore the feasibility of performing them in a therapeutic study. Third, the outcome of this initial study of the long-term use of an aerosolized diuretic agent in humans involved questions of drug safety. We monitored our patients for any adverse effect of amiloride as a potassiumsparing diuretic agent and for deleterious effects on pulmonary function. Finally, because amiloride is not approved for use in children, we selected a cohort of adults.

The long-term inhalation of amiloride produced no pulmonary or systemic toxicity. No patient had either drug-related bronchoconstrictive symptoms or reductions in gas exchange or diffusing capacity that might indicate alveolar toxicity. No adverse effects of amiloride were seen on hematologic or liver-function tests or measurements of vascular volume, renal function, or serum electrolytes. These findings are consistent with those from animal studies ${ }^{24,25}$ (and Boucher RC, et al.: unpublished data).

Amiloride aerosol appears to slow the decline in pulmonary function associated with cystic fibrosis. The rate of loss of FVC was reduced by approximately 50 percent during the amiloride period as compared with the vehicle period. However, a significant difference in $\mathrm{FEV}_{1}$ was not observed. This relatively smaller change in $\mathrm{FEV}_{1}$ parallels the pattern of spirometric changes reported in studies exploring the efficacy of antibiotics in patients with cystic fibrosis. ${ }^{26}$ Because 
Table 4. Summary of Drug Interventions in Each Study Period.*

\begin{tabular}{|c|c|c|c|c|c|c|}
\hline \multirow[t]{2}{*}{ Drug } & \multicolumn{2}{|c|}{ Vehicle } & \multicolumn{2}{|c|}{ AMILORIDE } & \multicolumn{2}{|c|}{ DIFFERENCE $\dagger$} \\
\hline & $\begin{array}{l}\text { NO. OF } \\
\text { INTER- } \\
\text { VENTIONS }\end{array}$ & $\begin{array}{l}\text { WEEKS } \\
\text { OF USE }\end{array}$ & $\begin{array}{l}\text { NO. OF } \\
\text { INTER- } \\
\text { VENTIONS }\end{array}$ & $\begin{array}{l}\text { WEEKS } \\
\text { OF USE }\end{array}$ & $\begin{array}{l}\text { NO. OF } \\
\text { INTER- } \\
\text { VENTIONS }\end{array}$ & $\begin{array}{l}\text { WEEKS } \\
\text { OF USE }\end{array}$ \\
\hline $\begin{array}{l}\text { Antibiotics } \\
\text { (oral) }\end{array}$ & 22 & 95 & 24 & 74 & $\begin{array}{l}-0.14 \\
\pm 0.44\end{array}$ & $\begin{array}{r}1.50 \\
\pm 1.77\end{array}$ \\
\hline $\begin{array}{l}\text { Bronchodilators } \\
\text { (inhaled } \\
\text { or oral) }\end{array}$ & 9 & 23 & 2 & 7 & $\begin{array}{r}0.50 \\
\pm 0.37\end{array}$ & $\begin{array}{r}1.14 \\
\pm 0.79\end{array}$ \\
\hline $\begin{array}{l}\text { Corticosteroids } \\
\quad \text { (oral) }\end{array}$ & 1 & 3 & 1 & 2 & - & - \\
\hline
\end{tabular}

*Medications that were administered after extraondinary intervention in three patients are no included.

tMean ( \pm SEM) difference per patient between values in the vehicle period and the amiloride period. No differences were statistically significant.

the effects of vehicle and amiloride were compared after parenteral antibiotic therapy, the decline in FVC during vehicle may have been more rapid than usual.

We analyzed drug interventions to determine whether the effects of amiloride on spirometric features could be attributed to differences in medical therapy. It is clear that these effects were not due to excessive intervention with bronchodilators and oral antibiotics during treatment with amiloride.

The mechanism of amiloride's beneficial effect is uncertain. The effect does not appear to reflect a direct bronchodilating activity of amiloride, because differences in FVG between the study periods persisted after the administration of beta-agonist bronchodilators, and no acute bronchodilating effect of amiloride has been observed in patients with cystic fibrosis. ${ }^{14,27}$ The effect also does not appear to reflect a direct antimicrobial action of amiloride, ${ }^{28-30}$ because bacterial densities did not differ between study periods. Therefore, it is more likely that amiloride exerts a beneficial effect at least in part by increasing the clearance of secretions, as has been reported in short-term studies. ${ }^{27}$

We hypothesized that amiloride might increase the clearance of airway secretions by improving their biorheologic properties. There are few available data that directly measure the rheologic features of sputum as an index of therapeutic efficacy. ${ }^{31}$ To test the feasibility of performing such measurements, we collected sputum specimens at the end of each period and studied them in a blinded fashion, using techniques developed by Puchelle et al. ${ }^{13}$ Indexes of sputum rheologic features were better after long-term treatment with amiloride than after treatment with vehicle, and they period. by 2.774 . were similar to values reported for healthy subjects. ${ }^{21}$ The biorheologic changes predict increases in the rates of mucociliary transport and cough clearance that are consistent with those reported in short-term studies of aerosolized amiloride. ${ }^{27}$

We did not detect the change in the percentage of solids in dried sputum that would be expected if amiloride improved the rheologic features of mucus by increasing its water content. This finding may reflect the insensitivity of the techniques employed to detect small but functionally important changes in the water content of sputum. Further studies are required to establish the mechanism of amiloride's effects on the viscosity, elasticity, and clearance of mucus.

In conclusion, this study of a small number of patients provides preliminary evidence that amiloride may be moderately effective in the treatment of adults with cystic fibrosis and established lung disease.

We are indebted to Al Spock, M.D., and Al Driver, M.D., for patient referrals; Brian Boehlecke, M.D., Floyd Denny, M.D., and Arnold Smith, M.D., for discussions of study design; Kathleen McCarroll, Ph.D., for assistance in planning data collection and storage; Nancy Anderson for assistance in design of the computer data base; Beth Funk, M.D., David Henke, M.D., Richard Mann, M.D., Raphael Perez, M.D., and Lorraine Trow, M.D., for patient management; Betty Hornaday for special assistance with pulmonary-function testing; Richard Kowalski, Ph.D., for assistance in lung scans; David Delany, M.D., and Al Parker, M.D., for reviewing and scoring chest radiographs and lung scans; Mary George, Ph.D., and Ric Hodinka, Ph.D., for performing quantitative bacterial sputum cultures; Oscar Ramirez, M.D., and J. Gustavo Zayas, M.D., for sputum rheologic analysis; Cynthia Taylor and Teresa Mace for assistance in specimen and data collection; Martha Clarke, R.N., and personnel of the clinical research unit for special assistance in patient management; Gerald Fernald, M.D., for monitoring of toxicity as a blinded nonparticipant; Gerald Strope, M.D., Eastern Virginia Medical School, for serving as an external reviewer

Table 5. Indexes of Systemic Salt and Water Metabolism during the Study Periods.*

\begin{tabular}{|c|c|c|c|c|}
\hline \multirow[t]{2}{*}{ INDEX } & \multicolumn{2}{|c|}{ VehicLe } & \multicolumn{2}{|c|}{ AMILORIDE } \\
\hline & BASE LINE & $\begin{array}{c}\text { DURING } \\
\text { TREATMENT }^{\dagger}\end{array}$ & BASE LINE & $\begin{array}{c}\text { DURING } \\
\text { TREATMENT }{ }^{\dagger}\end{array}$ \\
\hline Weight $(\mathbf{k g})$ & $59.9 \pm 2.3$ & $59.7 \pm 2.4$ & $59.8 \pm 2.4$ & $59.6 \pm 2.2$ \\
\hline $\begin{array}{l}\text { Blood pressure }(\mathrm{mm} \mathrm{Hg}) \ddagger \\
\text { Systolic } \\
\text { Diastolic }\end{array}$ & $\begin{array}{r}114.5 \pm 2.6 \\
74.2 \pm 2.3\end{array}$ & $\begin{array}{r}110.9 \pm 1.5 \\
71.4 \pm 2.1\end{array}$ & $\begin{array}{r}111.6 \pm 2.5 \\
70.2 \pm 2.3\end{array}$ & $\begin{array}{r}113.0 \pm 2.0 \\
71.7 \pm 1.4\end{array}$ \\
\hline Pulse (per min) $\ddagger$ & $91.1 \pm 4.6$ & $100.7 \pm 3.4 \S$ & $90.8 \pm 2.3$ & $94.5 \pm 2.5$ \\
\hline Serum sodium (mmol/liter) & $139.1 \pm 0.5$ & $138.6 \pm 0.3$ & $138.2 \pm 0.6$ & $139.0 \pm 0.5 \uparrow$ \\
\hline Serum potassium (mmol/liter) & $4.2 \pm 0.1$ & $4.0 \pm 0.1$ & $4.1 \pm 0.1$ & $4.1 \pm 0.1$ \\
\hline Serum urea nitrogen $(\mathrm{mg} / \mathrm{d}) \|$ & $14.1 \pm 1.2$ & $13.4 \pm 0.9$ & $14.6 \pm 1.1$ & $12.8 \pm 0.8 \S$ \\
\hline Serum creatinine $(\mathrm{mg} / \mathrm{dl})^{* *}$ & $0.8 \pm 0.1$ & $0.9 \pm 0.1$ & $1.0 \pm 0.1$ & $0.9 \pm 0.1 \S \uparrow$ \\
\hline Urinary aldosterone $(\mu \mathrm{g} / 24 \mathrm{hr}) \dagger^{\dagger}$ & $10.3 \pm 1.7$ & $10.6 \pm 3.4$ & $13.8 \pm 2.0$ & $15.8 \pm 2.6$ \\
\hline
\end{tabular}

*Plus-minus values are means \pm SEM.

†Values are means of all measurements reconded during the treatment period for all values except aldosterone, which reflects a single 24-hour urinary measurement at the end of the period.

fIn a standing position.

$\S \mathrm{P}<0.05$ by paired $\mathrm{t}$-test for the comparison with base line

IP $<0.05$ by paired $\mathrm{t}$-test for the comparison of the change during the amiloride period with the change during the vehicle

|To convert milligrams per deciliter to millimoles per liter, multiply by 0.3570

**To convert milligrams per deciliter to micromoles per liter, multiply by 88.4

††Normal range, 2 to $25 \mu \mathrm{g}$ per 24 hours. Values are for only nine patients. To convert micrograms to nanomoles, multiply 
of study design, data collection, and primary data; Thomas Boat, M.D., Robert Wood, M.D., and Philip Bromberg, M.D., for useful discussions and critical review of the manuscript; Lisa Brown and Rachel Knowles for assistance in preparation of the manuscript; Biomedical Home Care for generous support and the management of parenteral antibiotic therapy; DeVilbiss Healthcare for the donation of nebulizers and Pulmoaide compressed-air generators; Glaxo for the donation of Fortaz (ceftazidime); SensorMedics for the donation of pulmonary-function equipment; Merck, Sharp \& Dohme for the donation of amiloride hydrochloride; and, finally, the patients and their families for their diligence and sense of humor throughout the study.

\section{REFERENCES}

1. Boucher RC, Stutts MJ, Knowles MR, Cantley L, Gatzy JT. $\mathrm{Na}^{+}$transport in cystic fibrosis respiratory epithelia: abnormal basal rate and response to adenylate cyclase activation. J Clin Invest 1986; 78:1245-52.

2. Boucher RC, Cotton CU, Gatzy JT, Knowles MR, Yankaskas JR. Evidence for reduced $\mathrm{Cl}^{-}$permeability and increased $\mathrm{Na}^{+}$permeability in cystic fibrosis human primary cell cultures. J Physiol (Lond) 1988; 405:77-103.

3. Knowles M, Gatzy J, Boucher R. Relative ion permeability of normal and cystic fibrosis nasal epithelium. J Clin Invest 1983; 71:1410-7.

4. Frizzell RA, Rechkemmer G, Shoemaker RL. Altered regulation of airway epithelial cell chloride channels in cystic fibrosis. Science 1986; 233:55860 .

5. Shoumacher RA, Shoemaker RL, Halm DR, Tallant EA, Wallace RW, Frizzell RA. Phosphorylation fails to activate chloride channels from cystic fibrosis airway cells. Nature $1987 ; 330: 752-4$.

6. Li M, McCann JD, Liedtke CM, Naim AC, Greengard P, Welsh MJ. Cyclic AMP-dependent protein kinase opens chloride channels in normal but not cystic fibrosis airway epithelium. Nature 1988; 331:358-60.

7. Potter JL, Matthews LW, Spector S, Lemm J. Studies on pulmonary secretions. II. Osmolality and the ionic environment of pulmonary secretions from patients with cystic fibrosis, bronchiectasis, and laryngectomy. Am Rev Respir Dis 1967; 96:83-7.

8. Newhouse MT, Rossman CM, Dolovich J, Dolovich MB, Wilson WM. Impairment of mucociliary transport in cystic fibrosis. Mod Probl Paediatr 1976; 19:190-8.

9. Wood RE, Boat TF, Doershuk CF. Cystic fibrosis. Am Rev Respir Dis 1976; 113:833-78.

10. Knowles M, Murray G, Shallal J, et al. Bioelectric properties and ion flow across excised human bronchi. J Appl Physiol 1984; 56:868-77.

11. Knowles M, Gatzy J, Boucher R. Increased bioelectric potential difference across respiratory epithelia in cystic fibrosis. N Engl J Med 1981; 305:148995.

12. Waltner WE, Boucher RC, Gatzy JT, Knowles MR. Pharmacotherapy of airway disease in cystic fibrosis. TIPS 1987; 8:316-20.

13. Puchelle E, Toumier JM, Zahm JM, Sadoul P. Rheology of sputum collected by a simple technique limiting salivary contamination. J Lab Clin Med $1984 ; 103: 347-53$.
14. Waltner WE, Church NL, Gatzy JT, Boucher RC, Knowles MR. Toxicity and pharmacokinetics of acute amiloride aerosol in normal and cystic fibrosis subjects. Cystic Fibrosis Club Abstr 1986; 27:121. abstract.

15. Idem. Deposition, pharmacokinetics, and toxicity of amiloride aerosol in normal and cystic fibrosis (CF) subjects. Am Rev Respir Dis 1987; 135: Suppl:A288. abstract.

16. American Thoracic Society. Standardization of spirometry - 1987 update. Am Rev Respir Dis 1987; 136:1285-98.

17. Hodinka RL, Gilligan P, Gage P, Wait K, Knowles M. Quantitative bacteriology of sputum from cystic fibrosis patients. Presented at the 84th Annual Meeting of the American Society for Microbiology, Miami Beach, Fla., May 8-13, 1988. abstract.

18. Høiby N. Microbiology of lung infections in cystic fibrosis patients. Acta Paediatr Scand Suppl 1982; 301:33-54.

19. King M, Macklem PT. Rheological properties of microliter quantities of normal mucus. J Appl Physiol 1977; 42:797-802.

20. Brasfield D, Hicks G, Soong $S$, Tiller RE. The chest roentgenogram in cystic fibrosis: a new scoring system. Pediatrics 1979; 63:24-9.

21. Jeanneret-Grosjean A, King M, Michoud MC, Lioté H, Amyot R. Sampling technique and theology of human tracheobronchial mucus. Am Rev Respir Dis 1988; 137:707-10.

22. King $\mathbf{M}$, Brock $\mathbf{G}$, Lundell $\mathrm{C}$. Clearance of mucus by simulated cough. J Appl Physiol 1985; 58:1776-82.

23. Demedts M. Assessment of airway secretions by pulmonary function tests Eur J Respir Dis 1987; 71:330-3.

24. Mentz WM, Brown JB, Friedman M, Stutts MJ, Gatzy JT, Boucher RC Deposition, clearance, and effects of aerosolized amiloride in sheep airways. Am Rev Respir Dis 1986; 134:938-43

25. Boucher RC, James MK, Friedman M, Fullton J, Pimmel R, Gatzy JT. Acute cardiovascular and pulmonary effects of intravenous and aerosolized amiloride in the dog. Toxicol Appl Pharmacol 1987; 87:264-75.

26. Smith AL, Redding G, Doorshuk C, et al. Sputum changes associated with therapy for endobronchial exacerbation in cystic fibrosis. J Pediatr 1988, 112:547-54.

27. Köhler D, App E, Schmitz-Schumann M, Würtemberger G, Matthys H. Inhalation of amiloride improves the mucociliary and the cough clearance in patients with cystic fibrosis. Eur J Respir Dis Suppl 1986; 146:319. 26.

28. Cohn RC, Jacobs M, Aronoff SC. In vitro activity of amiloride combined with tobramycin against Pseudomonas isolates from patients with cystic fibrosis. Antimicrob Agents Chemother 1988; 32:395-6

29. Lisker A, Gilligan $P$, Wait $K$, Knowles $M$. In vitro activity of amiloride against bacteria isolated from patients with cystic fibrosis. Pediatr Pulmonol 1987; 3:Suppl:126. abstract.

30. George $\mathbf{M}$, Knowles $\mathbf{M}$, Gilligan $\mathbf{P}$. In vitro activity of amiloride congeners against bacteria isolated from patients with cystic fibrosis (CF). Presented a the 84th Annual Meeting of the American Society for Microbiology, Miami Beach, Fla., May 8-13, 1988. abstract.

31. King M. Mucus, mucociliary clearance and coughing. In: Bates DV, ed. Respiratory function in disease. 3rd ed. Philadelphia: W.B. Saunders, 1989:69-78. 